\title{
Occupational health needs of universities: a review with an emphasis on the United Kingdom
}

\author{
K M Venables, S Allender
}

Occup Environ Med 2006;63:159-167. doi: 10.1136/oem.2005.022145

This study describes the needs of universities in relation to planning the provision of occupational health services, by detailing their occupational hazards and risks and other relevant factors. The paper presents the results of (1) an enquiry into publicly available data relevant to occupational health in the university sector in the United Kingdom, (2) a literature review on occupational health provision in universities, and (3) selected results from a survey of university occupational health services in the UK. Although the enquiry and survey, but not the literature review, were restricted to the UK, the authors consider that the results are relevant to other countries because of the broad similarities of the university sector between countries. These three approaches showed that the university sector is large, with a notably wide range of occupational hazards, and other significant factors which must be considered in planning occupational health provision for individual universities or for the sector as a whole.

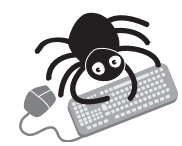

Appendices to this article are available on the OEM website (www. occenvmed.com/ supplemental)

See end of article for authors' affiliations

.....................

Correspondence to:

KM Venables, Department of Public Health, University of Oxford, Rosemary Rue Building, Old Road Campus, Headington Oxford OX3 7LF, UK; kate. venables@dphpc.ox.ac.uk

Accepted

1 September 2005
$\mathrm{T}$ he university sector in most countries is large, growing, includes employers with widely varying organisational cultures, and involves high risk exposures. Despite its risk and complexity, little has been written about the occupational health needs of this employment sector. By "needs" is meant not only information about hazard and risk, but also other informaprovision in universities. Such information might include, for example, relevant guidance on the health of special groups, such as medical students; relevant legislation, such as on health surveillance of research workers exposed to animals; and other information, such as on the size of universities, the age distribution of university staff and students, and the pattern of employment in universities, which is determined by university funding arrangements.

Only a limited number of relevant guidance documents have been published. The United Kingdom Health and Safety Commission published guidance on occupational health services in universities in 1991. ${ }^{1}$ Although the American College Health Association also published guidance in 1984, this is primarily about student health services. ${ }^{2}$ The Department for Education and Employment (now Department for Education and Skills) in the UK has published tion relevant to planning occupational health guidance on fitness to teach which, although focussed on primary and secondary education, has some relevance to higher education. ${ }^{34}$

We have carried out this review of occupational health needs of universities as part of a larger programme of research on occupational health provision in universities.

\section{METHODS}

Enquiry into publicly available information about universities in the UK

No central point for information about occupational health needs of universities in the UK was identified. The websites of organisations potentially holding relevant information were searched and follow up enquiries made by telephone, as required. The main organisations contacted are listed in online appendix 1 (see http://www.occenvmed.com/supplemental).

\section{Literature review}

Computerised searches were carried out using Medline, CINAHL, EMBASE, HMIC, and Science Citation Index from the start of each electronic database to September 2003. Key words were "occupation", "health", "services", "provision", "access", "university", "colleges", "higher education", and "polytechnic". Wildcards were used to truncate search terms and the search was not limited by language. Both authors reviewed titles, and papers were discarded if both authors thought they were irrelevant. The process was repeated after reading the abstracts of those retained, and again after reading the full text of all remaining papers. We obtained additional publications from the reference lists of the remaining papers and by means of general reading. In addition, we asked the membership of Higher Education Occupational Physicians, a special interest group of the Society of Occupational Medicine, to inform us of any relevant papers.

Of the 2568 papers identified in the initial search, only 58 were retained in the final review. The use of "university", "higher education", and "college" as search terms resulted in a large number of irrelevant papers which were rejected on the basis of title or abstract, often because the search terms had picked up the authors' affiliations. Other papers were excluded relating to the teaching of occupational health in universities, the practice of outpatient occupational medicine in university clinics, and the health concerns of healthcare workers in university hospitals. Papers which reported the use of university staff or students as convenient research subjects in tangential studies were also excluded. 


\section{Survey of university occupational health services in the UK}

Information was abstracted from the responses of the lead clinicians in university occupational health services to a question about "major hazards or other occupational health concerns". This question was included in a repeated cross sectional survey of occupational health provision in universities carried out in 2002, 2003, and 2004. A detailed account of the methodology is provided elsewhere. ${ }^{5}$ Responses to the three surveys have been combined. Where a respondent reported the same hazard or concern in more than one survey, it was counted once only. Minimal recoding was undertaken.

\section{RESULTS \\ Enquiry into publicly available information about universities \\ History of universities in the UK}

The history of universities in the UK has been reviewed by Graham (2002). ${ }^{6}$ The earliest, such as Oxford, Cambridge, and St Andrew's, are mediaeval foundations. In 1836 the University of London was formed with a federal structure and at the time included a number of colleges outside London. During the 1840s University Colleges were created in Belfast, Dublin, and Cork. The University of Wales also adopted a federal structure. Some of the colleges of the University of London, such as those in Bristol, Birmingham, and Manchester, grew to become universities in their own right, known as the "red brick" universities. Women were admitted in 1880 .

The Robbins report of $1963^{7}$ recommended the creation of additional new universities. Before the Robbins report, less than $10 \%$ of eligible school leavers continued to higher education. After the report, new universities were created and some pre-existing non-university institutions became autonomous, degree awarding bodies. Education reform in the late 1980s and early 1990s allowed polytechnics to apply for university status and led to the "post 1992" universities. By the mid-1990s, around a third of eligible school leavers in the United Kingdom continued to higher education and current government plans are for this to increase.

\section{Current state of universities in the UK}

The recent past has been characterised by mergers as well as the granting of university status to some previously nonuniversity institutions. A university has the power to award its own degrees, by research and teaching; a university college provides taught and research degrees, accredited by a university; a college of higher education provides taught degrees only, accredited by a university; this review does not include further education, which offers post-secondary education, often of a vocational nature, without awarding degrees. As of August 2004, there were 90 publicly funded universities (table 1). There were also 27 publicly funded institutions, many of large size, which are constituent parts of the federal universities of London and Wales but which are treated as distinct entities by funding and regulatory bodies. The single, privately funded university in the UK has been excluded from consideration because it does not provide statistical data. Colleges of higher education have also been excluded from consideration.

In 2003-04 there were 2247440 students and 338104 staff (table 2). There are large differences between the number of individuals and full time equivalents, indicating a large number of part time staff and students: staff 338104 and 280 147; postgraduate students 523827 and 302 576; undergraduate students 1723613 and 1323484 .

The size of university populations varies greatly between institutions (see online appendix 3 at http://www.occenvmed. com/supplemental). In 2003-04 the median number of staff was 1605; the range was from 30 in a small specialised dance school to 10883 in a university which specialises in distance learning for mature students and which employs many part time staff. Student numbers had a median of 11 994, ranging from 154 in the same dance school to 169221 in the same university. The total number of students and staff together had a median of 13291 , ranging from 519 in a specialist postgraduate institute to 180104 in the same university.

Some of the information on staff and students collected routinely by the Higher Education Statistics Agency is relevant to occupational health needs (table 2). The information is collected differently for staff and students and for different purposes. The likely explanation for the apparently larger percentage of disabled students (8\%) than staff $(2 \%)$ is that students are encouraged to declare disabilities, such as dyslexia, which might affect their learning so that they can access specialist services whereas there are fewer incentives for a member of staff to declare a disability. Table 2 illustrates that a high proportion (31\%) of university staff work on fixed term contracts, a proportion which is higher in the research intensive universities (data not presented). Table 2 also illustrates the wide range of occupations held by university staff, less than half of whom are described as "academic professionals".

The higher education sector is also large in economic terms and in 2002-03 its annual income was $£ 15.2$ billion. Figure 1 shows that income came from several sources, mainly funding council grants (39\%), tuition fees and education grants and contracts (24\%), and research grants and contracts $(17 \%)$. The pattern of funding varies considerably by institution and the proportion of funding from research grants and contracts is much higher in the research intensive universities (data not presented). This has implications for institutional management, including the provision of occupational health services, because income from research grants and contracts is dedicated to specific purposes, leaving no flexibility to cover, for example, adjustments to disability or responses to new health and safety regulations.

Some subject areas, such as medicine, dentistry, and other healthcare, are known to have higher than average

Table 1 Number of publicly funded universities and higher education institutions

\begin{tabular}{lcccr}
\hline & Universities & $\begin{array}{l}\text { Constituent parts of } \\
\text { federal universities }\end{array}$ & $\begin{array}{l}\text { Colleges of higher } \\
\text { education }\end{array}$ & Total \\
\hline England & 73 & 19 & 41 & 133 \\
Wales & 2 & 8 & 4 & 14 \\
Scotland & 13 & 0 & 7 & 20 \\
Northern Ireland & 2 & 0 & 2 & 4 \\
United Kingdom & 90 & 27 & 54 & 171
\end{tabular}

The names of institutions are provided in appendix 2 on the journal website at http://www.occenvmed.com/ supplemental.

Adapted from Universities UK. Higher education facts and figures, Summer 2004. Available at http:// bookshop.universitiesuk.ac.uk/downloads/facts04.pdf (accessed November 2004). 
Table 2 Characteristics of staff and students in United Kingdom universities in 2003-04

\begin{tabular}{|c|c|c|}
\hline & Count & $\%$ \\
\hline \multicolumn{3}{|l|}{ Staff } \\
\hline Total staff & 338104 & 100 \\
\hline Female & 177044 & 52 \\
\hline \multicolumn{3}{|l|}{ Age group } \\
\hline Under 21 & 4393 & 1 \\
\hline $21-30$ years & 58493 & 17 \\
\hline $31-40$ years & 50192 & 27 \\
\hline $41-50$ years & 88571 & 26 \\
\hline $51-60$ years & 79592 & 24 \\
\hline 61 and over & 15206 & 4 \\
\hline Age unknown & 2293 & 1 \\
\hline Declared disabled & 7360 & 2 \\
\hline \multicolumn{3}{|l|}{ Terms of employment } \\
\hline Open ended/permanent & 232792 & 69 \\
\hline Fixed term contract & 105312 & 31 \\
\hline \multicolumn{3}{|l|}{ Activity } \\
\hline Managers & 11664 & 3 \\
\hline Academic professionals & 150230 & 44 \\
\hline Non-academic professionals & 27168 & 8 \\
\hline $\begin{array}{l}\text { Laboratory, engineering, building, IT, } \\
\text { and medical technicians (including nurses) }\end{array}$ & 27243 & 8 \\
\hline $\begin{array}{l}\text { Student welfare workers, careers advisors, } \\
\text { vocational training instructors, personnel, } \\
\text { and planning officers }\end{array}$ & 7271 & 2 \\
\hline $\begin{array}{l}\text { Artistic, media, public relations, marketing, } \\
\text { and sports occupations }\end{array}$ & 4705 & 1 \\
\hline $\begin{array}{l}\text { Library assistants, clerks, and general } \\
\text { administrative assistants }\end{array}$ & 44515 & 13 \\
\hline $\begin{array}{l}\text { Secretaries, typists, receptionists, and } \\
\text { telephonists }\end{array}$ & 19596 & 6 \\
\hline $\begin{array}{l}\text { Chefs, gardeners, electrical and construction } \\
\text { trades, mechanical fitters, and printers }\end{array}$ & 5514 & 2 \\
\hline $\begin{array}{l}\text { Caretakers, residential wardens, sports and } \\
\text { leisure attendants, nursery nurses, and care } \\
\text { occupations }\end{array}$ & 4909 & 2 \\
\hline Retail and customer service occupations & 1123 & $<1$ \\
\hline $\begin{array}{l}\text { Drivers, maintenance supervisors, and } \\
\text { plant operatives }\end{array}$ & 1538 & 1 \\
\hline $\begin{array}{l}\text { Cleaners, catering assistants, security officers, } \\
\text { porters, and maintenance workers }\end{array}$ & 32630 & 10 \\
\hline \multicolumn{3}{|l|}{ Postgraduate students } \\
\hline Total postgraduate students & 523827 & 100 \\
\hline Female & 277104 & 53 \\
\hline Declared disabled & 37191 & 7 \\
\hline \multicolumn{3}{|l|}{ Undergraduate students } \\
\hline Total undergraduate students & 1723613 & 100 \\
\hline Female & 1004866 & 58 \\
\hline Declared disabled & 122377 & 7 \\
\hline \multicolumn{3}{|l|}{ All students } \\
\hline Total students & 2247440 & 100 \\
\hline Female & 1281041 & 57 \\
\hline Declared disabled & 159569 & 8 \\
\hline
\end{tabular}

Data from 117 universities; three had no postgraduate students, four no undergraduate students, and student numbers were not available for one.

occupational health needs. Table 3 illustrates that large numbers of university staff and students work in these subject areas. For staff, the Higher Education Statistics Agency collects the cost centre of the employing department and, for students, the subject of study, which have been combined under broad subject area headings in table 3.

\section{Literature review}

\section{Opinion pieces}

Summarising firstly the several opinion pieces retained from the literature search which responded to health and safety legislation from a university perspective, all made broadly similar comments that universities are large organisations, with very diverse though small scale hazards, a decentralised organisational structure, and a lack of clarity about responsibility for managing occupational health and safety issues. ${ }^{8-13}$

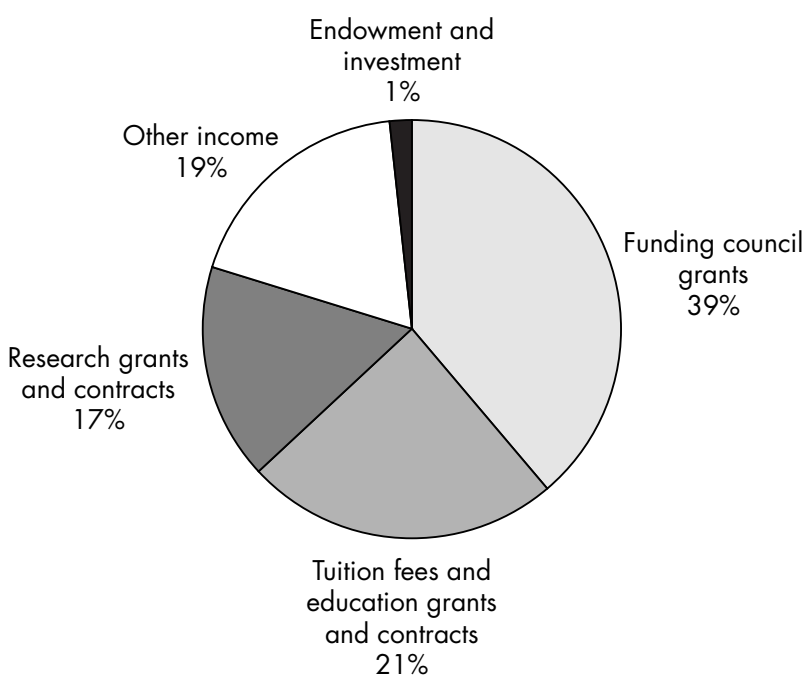

Total income $=£ 15.2$ billion

Figure 1 Sources of income in United Kingdom universities 2002-03.

People using university premises and services include many people (such as students and members of the public) with whom there is no employer-employee relationship. Compared to industry, work in universities is carried out with little training and supervision. Writing in 1979, Gunn commented that the high level of technical knowledge in universities meant that hazards were well managed before the United Kingdom Health and Safety at Work legislation and that there was a danger that increased regulation would stifle research. ${ }^{9}$ At a similar time, DeRoos commented that universities frequently work in new fields where there is little information about risk. ${ }^{8}$ From the legal perspective, new methodologies, such as genetic engineering, can raise complex issues. ${ }^{10}$ Some of the problems described by commentators were related to the change process as longstanding campus primary care services changed their role to become preventive services. ${ }^{13}$

\section{General surveys}

Turning to the limited evidence base of primary research identified in the literature review, a cross sectional postal survey of health and safety provision at 75 state funded colleges in the United States which had graduate programmes found that the majority (89\%) had identified physical, chemical, and biological hazards within the workplace and $70 \%$ reported a radiological hazard. ${ }^{14}$ An initial analysis suggested that colleges focussing on Black and other ethnic minority populations (which historically have had poor resources) had worse health and safety support than non-minority colleges (mean number of health and safety staff $1.14 v 3.12$ ) but this difference was explained by the number of full time college employees. A survey of 33 French universities in 1984 reported that more than half of them had no occupational health service, despite the high risk profile of many employees. ${ }^{15}$ There was no relation in this study between the presence of academic occupational medicine as a subject area and the presence of an occupational health service.

Four papers reported about single universities. Activities over 12 months in an American university occupational health service were reported ${ }^{16}$ and a limited amount of activity data from a French university. ${ }^{17}$ A descriptive cross sectional study of hazardous exposures, symptoms, and 
Table 3 Subject area of staff and students in United Kingdom universities in 2003-04

\begin{tabular}{lrrr}
\hline Subject area & Staff & $\begin{array}{c}\text { Postgraduate } \\
\text { students }\end{array}$ & $\begin{array}{l}\text { Undergraduate } \\
\text { students }\end{array}$ \\
\hline Medicine, dentistry, and other healthcare & 54226 & 55200 & 286349 \\
Biological, mathematical, and physical sciences & 38253 & 78671 & 310836 \\
Engineering and technology & 27848 & 38770 & 96034 \\
Agriculture, forestry, and veterinary science & 4724 & 4121 & 15292 \\
Architecture and planning & 3814 & 13568 & 34268 \\
Administrative, business, and social studies & 37073 & 152917 & 380428 \\
Language based studies & 9080 & 17497 & 117724 \\
Other arts & 24077 & 57590 & 271968 \\
Education & 17112 & 102935 & 90670 \\
Combined studies not otherwise specified & NA & 2557 & 120043 \\
Academic services & 29165 & NA & NA \\
Administration and central services & 52698 & NA & NA \\
Premises & 19090 & NA & NA \\
Residences and catering operations & 20942 & NA & NA \\
Total, all departments & 338104 & 523827 & 1723613 \\
\hline
\end{tabular}

NA, not applicable.

Data from 117 universities; three had no postgraduate students, four no undergraduate students, and student numbers were not available for one.

knowledge about personal protective equipment was carried out in one Venezuelan university in 2002, finding a positive relation between years spent working at the university and the number of symptoms reported. ${ }^{18}$ Compliance with preemployment health screening was studied at a Canadian university. ${ }^{19}$ Of 108 new employees interviewed, three quarters had been screened but less than $30 \%$ before starting work. Compliance was associated with notification of a legislative requirement for pre-employment screening and the employee's perception of the importance of pre-employment screening. All employees in "high risk" roles had undertaken pre-employment screening.

\section{University laboratories}

As an illustration of the potential hazards of university research, the last known death from smallpox in the world occurred in 1978 as a result of laboratory transmission in Birmingham University, UK. In 2002, Pennington summarised this outbreak for a lay readership..$^{20}$ In a survey of workers in virus laboratories at one US university in $1975,{ }^{21}$ Stark commented that although the transmission rate appeared low the severity of many viral illnesses is high and his observation can be generalised to a wide range of university research. Universities are not the only places where laboratory work is carried out and this review did not aim to identify all studies on the health risks of laboratory work. We did identify a retrospective cohort study of pregnancy outcomes in first births to Swedish female research laboratory employees from 1970 to 1989 which found an increased risk of pre-term birth related to work with solvents and an increased risk of post-term birth related to work with bacteria. $^{22}$

In the literature review, papers were identified describing radiation protection in biomedical research, ${ }^{23}$ laser safety, ${ }^{24}$ performance evaluation of specialty local exhaust ventilation systems ${ }^{25}$ walkthrough surveys of university chemistry laboratories, ${ }^{26}$ and disposal of biohazardous waste. ${ }^{27}$ Laboratories have been a concern for unions as well as occupational health professionals. ${ }^{28}$

There have been two large surveys focussing on the institutional response to risks in university laboratories. Goodwin et al (1999 $)^{29}$ surveyed all 33 Australian universities offering courses in chemistry and found that occupational health and safety training for students and staff was variable in amount and content and was frequently not assessed along with other coursework. Rombeck and Schacke $(2000)^{30}$ identified 13764 different chemical substances in their survey of 11 German medical university institutes.
Although most institutions were attempting to comply with the recent regulations which had prompted the study, the authors identified a lack of listing of chemicals and of internal policies and guidance for workers, a need for substitution of carcinogenic and toxic chemicals with less toxic alternatives, a complete lack of occupational health surveillance for students and a need for a more proactive occupationally focussed service for staff.

\section{Staff and students in clinical environments}

Of the many studies of the epidemiology of infection by bloodborne viruses, some have included medical students and other healthcare students. For example, 193 needlestick injures or other exposures were reported in a questionnaire survey among 312 clinical medical students in one year in one US medical school, 11 involving a known HIV risk. ${ }^{31}$ Ten years later a similar level of reporting was found in another US medical school, with 60 reports among 119 clinical medical students over one year, with a higher risk during surgery and obstetrics and gynaecology than during other clerkships. ${ }^{32}$ In a third US medical school, $12 \%$ of 298 of the exposures to blood and other body fluids reported to the occupational health service over one year were to healthcare students, with dental students having the highest risk and nursing students the lowest, medical students being intermediate. ${ }^{33}$ The management of these injuries in students and faculty has been discussed..$^{34}$ One study suggested that the prevalence of markers of hepatitis B infection increases with years of clinical experience in students and staff at an Indian medical school. ${ }^{35}$ Good uptake of hepatitis B vaccination by medical students was reported at one US university. ${ }^{36}$ We retained one paper ${ }^{37}$ which reported on curriculum initiatives to address the prevention of risks.

Other commentators have observed that healthcare students remain vulnerable to airborne infection as well as those spread by inoculation injury. For example, an outbreak of tuberculosis occurred in 1979 in Australian medical students who attended the autopsy of a patient with active tuberculosis in which eight of 35 Mantoux negative students converted to positive, one developing clinical disease. This incident was reported 15 years later in order to highlight the increasing tuberculosis risk to students following its reemergence as an opportunistic infection in AIDS patients. ${ }^{38}$ In pre-antibiotic days, tuberculosis contracted from autopsy exposures was a significant risk to medical students. ${ }^{39} \mathrm{~A}$ study of the tuberculin conversion rate in dental students in a US dental school in 1996 showed an annual conversion rate of $10 \%$, comparable to that in the pre-antibiotic era, ${ }^{40}$ 
although the authors commented that the risk factors for conversion were complex. The tuberculin responsiveness of healthcare students was compared with non-healthcare students in one Colombian university and, reassuringly, no difference was found. ${ }^{41}$

\section{Veterinary work}

Unsurprisingly, the risk of zoonotic infection in veterinary schools has led to concerns. "Numerous" rabies exposures were reported between 1970 and 1977 at one American university leading to post-exposure prophylaxis of at least 200 veterinary students. ${ }^{42}$ In 1989, 3\% of French veterinary students from one university were reported to have a positive skin test reaction to Brucella abortus antigen, with a higher prevalence (6\%) in final year students. ${ }^{43}$ In 1978 , a survey of health and safety organisation in all of the 22 veterinary schools in the US found that none had dedicated health and safety officers, although most had access to advice elsewhere in the university and most had a health and safety committee. ${ }^{44}$

\section{Arts}

The arts are not immune from risk and McCann (2001) has reviewed the issue of health and safety programmes for art and theatre schools. ${ }^{45}$ Lucas and Salisbury (1992) identified a number of serious hazards in the visual arts department in one university, highlighting respirable free silica in sandblasting, wood dust, and noise which all exceeded relevant US exposure limits, as well as toxic concentrations of toluene and methyl cellosolve acetate in painting and printmaking. ${ }^{46}$ $\mathrm{Lu}$ (1992) commented that staff and students in arts departments are often unaware of the health risks of common chemicals in their working environment. ${ }^{47}$

Performing artists also face a wide variety of occupational health problems. A case control study of playing related musculoskeletal disorders among professional and university student classical musicians within one Canadian province showed that females and string players had an increased risk. $^{48}$ In one American university almost $90 \%$ of the 117 music students surveyed had experienced a playing related injury at some time and almost $80 \%$ felt that some musical knowledge was important in the treatment of playing related injuries. ${ }^{49}$ A laryngeal examination in 65 asymptomatic singing students at one American university showed that $8 \%$ had early signs of benign vocal fold lesions and $73 \%$ had some posterior erythema. ${ }^{50}$ A study of one American university jazz band found that Occupational Safety and
Health Administration noise exposure limits were exceeded indicating an increased risk of hearing loss. ${ }^{51}$

\section{Other specific topics}

Universities have very diverse research environments and, for example, the review identified a three year study of illness and injuries among the crew, scientists, students, and technical staff on 26 oceanographic research vessels representing 18 US universities and research institutes..$^{52} 122$ cases required medical tele-consultation and $20 \%$ required medical evacuation or diversion of the ship. Thirty one per cent of cases were injuries and the remainder were medical cases, $34 \%$ related to infection, $12 \%$ to sexually transmitted disease, and $23 \%$ to non-infection causes.

Most universities have extensive and complex estates and facilities and the occupational health problems related to their repair and maintenance have been little studied. The review identified one report on the lead exposure during custodial activities of 16 workers at one American university. ${ }^{53}$

University staff make extensive use of computers but appear to have been used as convenience samples for ergonomic research rather than studied in their own right. An exception was an evaluation of an office ergonomics training programme in one American university by means of a one year follow up of a sample of 200 programme participants. The programme was found to have changed behaviour in $95 \%$ of respondents and increased postural awareness in $86 \% .^{54}$

\section{Health of university staff}

To aid comprehension, this section contains information obtained from the enquiry as well as information from the literature review. The common perception that university staff are healthier than the average is probably based on the mortality experience of university lecturers, rather than university staff as a whole. In the UK, the standardised mortality ratio (SMR) for university lecturers is consistently less than 100 (table 4) ${ }^{55-57}$ University lecturers also appear to experience lower mortality than other teachers. For example, in 2001 for men, the SMR was 44 for teachers in higher education, 90 for teachers in further education, and 91 for all other teachers. Other university occupations (such as librarian, researcher, administrator, clerical officer) are not unique to the university sector, making it difficult to examine the mortality experience of university employees as a whole. It seems reasonable to assume that social status, education, and lifestyle factors will have a beneficial effect on the

Table 4 Population estimates and standardised mortality ratios for male university academics in the United Kingdom for census years 1961-2001

\begin{tabular}{|c|c|c|c|c|c|c|c|c|}
\hline Census & $\begin{array}{l}\text { Occupation } \\
\text { (numerical code) }\end{array}$ & Description & Countries & $\begin{array}{l}\text { Age range } \\
\text { (years) }\end{array}$ & Population & $\begin{array}{l}\text { Observed } \\
\text { deaths }\end{array}$ & $\begin{array}{l}\text { Expected } \\
\text { deaths }\end{array}$ & SMR \\
\hline 1961 & $\begin{array}{l}\text { University teachers } \\
(286)\end{array}$ & $\begin{array}{l}\text { Persons lecturing or tutoring at } \\
\text { universities or university colleges }\end{array}$ & $\begin{array}{l}\text { England \& } \\
\text { Wales }\end{array}$ & $15-64$ & 9790 & 68 & 101 & 67 \\
\hline 1971 & $\begin{array}{l}\text { University teachers } \\
\text { (192) }\end{array}$ & $\begin{array}{l}\text { Persons lecturing or tutoring at } \\
\text { universities or university colleges }\end{array}$ & $\begin{array}{l}\text { England \& } \\
\text { Wales }\end{array}$ & $15-64$ & 20270 & 127 & NA & 49 \\
\hline 1981 & $\begin{array}{l}\text { University academic } \\
\text { staff }(010.01)\end{array}$ & $\begin{array}{l}\text { Persons lecturing or teaching at } \\
\text { universities or university colleges }\end{array}$ & UK & $20-64$ & 31240 & 294 & NA & 48 \\
\hline 1991 & $\begin{array}{l}\text { University and } \\
\text { polytechnic teachers } \\
\text { (230) }\end{array}$ & $\begin{array}{l}\text { Deliver lectures and teach students to } \\
\text { at least first degree level, undertake } \\
\text { research and write journal articles and } \\
\text { books in their chosen field of study }\end{array}$ & $\begin{array}{l}\text { England \& } \\
\text { Wales }\end{array}$ & $20-64$ & 45090 & $465^{*}$ & 571 & $81^{*}$ \\
\hline 2001 & $\begin{array}{l}\text { Higher education } \\
\text { teaching professionals } \\
\text { (2311) }\end{array}$ & $\begin{array}{l}\text { Deliver lectures and teach students to } \\
\text { at least first degree level, undertake } \\
\text { research and write journal articles and } \\
\text { books in their chosen field of study }\end{array}$ & $\begin{array}{l}\text { England \& } \\
\text { Wales }\end{array}$ & $20-64$ & 53909 & 302 & 688 & 44 \\
\hline
\end{tabular}

*The interruption in the sequence of observed deaths and standardised mortality ratios in 1991 suggests that the coding rules for occupation at death may have changed in 1991.

NA, not available. 
mortality and morbidity of many occupational groups in universities. Indeed, a survey of cardiovascular risk factors, including blood pressure, in all 730 staff at one Australian university found that the risk of cardiovascular disease was lower than that of the general population. ${ }^{58}$

Considering the morbidity of university staff, the literature review identified two papers which were based on occupational disease registries. A Slovakian study $y^{59}$ concluded that university teachers and medical researchers were at increased risk of hepatitis, tuberculosis, toxoplasmosis, mycoplasma pneumonia, and leptospirosis in 1977-96, and, in a region of the Czech Republic, university staff were reported to be at increased risk of hepatitis, contact eczema, and allergic rhinitis. ${ }^{60}$

In the UK, the Health and Safety Executive funds a national reporting scheme for clinical diagnoses made by specialist physicians of work related and occupational ill health. This scheme involves sampling, with estimation of numbers of cases, so the data are approximate. For the six years 1998-2003, over 100000 cases were estimated to have been diagnosed, of which $2 \%$ worked in higher education (table 5). Of the cases reported from higher education, half were mental ill health. However, $80 \%$ of cases in the rest of the education sector were due to mental ill health. Other areas where there was a disparity between higher education and the rest of the education sector were musculoskeletal disorders $(30 \% \vee 8 \%)$ and respiratory diseases ( $10 \% \vee 2 \%)$. The education sector as a whole had proportionately fewer skin disorders and infectious diseases than other employment sectors (unpublished data, Health and Safety Executive).

Considering self reported ill health, the Self-Reported Work-Related Illness surveys in the UK collect information from general population samples on perceptions of work relatedness of ill health. For 2001-02, of the illnesses reported by higher education employees as caused or made worse by work, $48 \%$ were stress, depression, or anxiety and 28\% were musculoskeletal disorders (unpublished data, Health and Safety Executive).

Stansfeld et al (2003) carried out a secondary analysis of the Second Survey of Psychiatric Morbidity, a national survey by the Health and Safety Executive which was carried out in $2000 .{ }^{61}$ Although teaching professionals were identified as a group with a raised prevalence of indices of common mental disorder, the excess was found to be in primary and secondary education, rather than in higher education.

\section{Stress}

Stress has been a particular concern of university staff in the UK in recent years and has been the subject of two monographs. ${ }^{62}{ }^{63}$ One reported a recent survey carried out by the Association of University Teachers ${ }^{63}$ which found that
$69 \%$ of academic and related staff found their job stressful and $50 \%$ reported psychological distress. A major study was carried out recently by Tytherleigh et al (2005). ${ }^{64}$ All employee groups in 14 higher education institutions in the UK were included and surveyed by means of a standardised questionnaire; 3800 questionnaires were returned, a response rate of $38 \%$. The results showed that the most significant source of stress was job insecurity. In comparison to normative data, staff also reported significantly higher levels of stress relating to work relationships, control, and resources and communication, and significantly lower levels of commitment both from and to their organisation. However, they also reported significantly lower levels of stress relating to work/life balance, overload, and job overall, and lower levels of physical ill health.

One study of staff in a former polytechnic in the UK hypothesised that increasing pressure to be research active was a stressor for academic staff whose former polytechnic employer had now become a university. Although the results failed to confirm this, the study was small. ${ }^{65}$ Another small study of 30 staff in a Cypriot university found increased levels of stress using the Occupational Stress Indicator. ${ }^{66} \mathrm{~A}$ focus group study of 178 staff in 15 Australian universities found that associations with stress included insufficient funding and resources, poor management, job insecurity, and poor recognition and reward for work. ${ }^{67}$ Similar associations were found with stress in a Canadian university. ${ }^{68}$ A qualitative study of 30 Brazilian nursing professors identified financial concerns and working double or triple shifts as additional stressors. ${ }^{69}$

Several papers identified in the literature review reported on employee assistance or wellness programmes. Two studies identified alcohol abuse, marital, family, and emotional problems as issues for university staff. $^{70}$ One paper discussed the special issues relevant to introducing an alcohol policy in a university in Australia. ${ }^{72}$ A survey of the wellness needs of 408 of 1326 staff in one American university showed that the topics of most interest to the staff were stress, exercise and fitness, and nutrition and diet. ${ }^{73}$

\section{Survey of university occupational health services}

The "main hazards and other occupational health concerns" in UK universities, as perceived by university occupational health service staff in 2002-04, are summarised in table 6. This shows that their main concerns which would be classified as specific occupational risks were perceived to be allergens, chemicals/laboratories, and infection. The main other concerns reported were stress, manual handling/ musculoskeletal disorders, and display screen equipment. Poor management was reported as a main concern by 13 universities.

Table 5 Work related and occupational ill health diagnosed by specialist physicians in the United Kingdom 1998-2003

\begin{tabular}{|c|c|c|c|c|c|c|}
\hline \multirow[b]{3}{*}{ Major disease category } & \multicolumn{4}{|c|}{ Education } & \multirow{2}{*}{\multicolumn{2}{|c|}{$\begin{array}{l}\text { All other employment } \\
\text { sectors }\end{array}$}} \\
\hline & \multicolumn{2}{|c|}{ Higher education } & \multicolumn{2}{|c|}{ Other education } & & \\
\hline & $\mathbf{n}$ & $\%$ & $\mathbf{n}$ & $\%$ & $\mathbf{n}$ & $\%$ \\
\hline Respiratory diseases & 243 & 10 & 81 & 2 & 9788 & 9 \\
\hline Skin disorders & 219 & 9 & 341 & 8 & 25355 & 22 \\
\hline Musculoskeletal disorders & 722 & 30 & 340 & 8 & 32506 & 28 \\
\hline Mental ill health & 1255 & 50 & 3555 & 80 & 35589 & 31 \\
\hline Infectious diseases & 20 & $<1$ & 95 & 2 & 6776 & 6 \\
\hline Audiological disorders & 25 & $<1$ & 10 & $<1$ & 3695 & 3 \\
\hline Other problems & 12 & $<1$ & 37 & $<1$ & 1162 & 1 \\
\hline Total diagnoses & 2496 & 100 & 4459 & 100 & 114871 & 100 \\
\hline
\end{tabular}




\section{DISCUSSION}

This review has demonstrated that there are many sources of information available which are relevant to a consideration of the occupational health needs of universities. This information does not appear to have been pulled together before. Some information was difficult to access. In particular, it proved technically difficult to retrieve published literature because the term "university" appeared as part of the author's address, or as part of the description of the source of subjects. We anticipate that this review will prove useful not only in the UK and in other developed countries, but more widely because of the broad similarities between universities in different countries.

The higher education sector in the UK is large and this is likely to be true in other developed countries. Including staff and students, the total number in the higher education sector in the UK is 2585 544. This can be compared to 2003 estimates for the health service ( 1.4 million), the police, including civilians (226 000), and the armed forces (206 000)..$^{74}$ It could be argued that students should not be included when assessing the size of a university because they are not employees. However, some groups of students, such as medical and dental students, are intensive users of university occupational health services. Furthermore, students-particularly postgraduate students-work in the same workplaces as employees and are subject to the same hazards.

It is difficult to think of another employment sector with such a wide range of hazards. In itself, this requires an occupational health and safety response from universities which is proportionately specialised and adaptable. The hazards include clinical environments, dangerous pathogens, genetically modified organisms, field work and overseas travel, allergens, hazardous chemicals, physical hazards such as radiation and lasers, manual handling, and work with computers. It could be argued that exposures to hazardous processes or materials in universities are much smaller in scale than in, say, manufacturing industry. Although this is generally true, universities have an extraordinarily varied and large number of hazards, some very specialised and exotic. It is likely that this variety of hazardous exposures requires a higher level of occupational health response than that needed in mono-hazard industries. Although our literature review showed a wide range of hazards, it almost certainly underestimates the range because of the special problems generated when "university" is one of the search terms. It identified no papers on laboratory animal allergy, for example, which is a well known risk for university staff and students engaged in research using animals. It is therefore particularly important when considering the occupational health needs of universities to draw information from a range of sources as well as the published literature.

The university workforce is unusual in many respects. Although the age distribution for staff is probably comparable to that of many other sectors, the large number of students means that a high proportion of workers are young and inexperienced and it is unclear if students receive more or less training and supervision than is received by young employees in other sectors. A high percentage of staff work on fixed term research contracts, which has

Table 6 "Main hazards and other occupational health concerns" reported by university occupational health services in surveys in 2002, 2003, or 2004

\begin{tabular}{|c|c|c|}
\hline Topic & Reports & Comments \\
\hline Stress & 70 & $\begin{array}{l}\text { Includes work overload, excess working hours, work/life balance, } \\
\text { depression, and anxiety }\end{array}$ \\
\hline $\begin{array}{l}\text { Manual handling and } \\
\text { musculoskeletal disorders }\end{array}$ & 52 & Includes caretakers and porters \\
\hline $\begin{array}{l}\text { Research animals, laboratory } \\
\text { animal allergy, asthma, and } \\
\text { allergies }\end{array}$ & 46 & $\begin{array}{l}\text { Includes generic respiratory and skin sensitisation; use of chemicals } \\
\text { and maintenance staff in animal houses; latex allergy in dentists }\end{array}$ \\
\hline $\begin{array}{l}\text { Chemicals and laboratory or } \\
\text { workshop hazards }\end{array}$ & 41 & $\begin{array}{l}\text { Includes unspecified health surveillance, sensitisation, toxicology and } \\
\text { chemicals; chemicals used in arts subjects; a wide range of specific } \\
\text { hazards, including solvents, acrylic resins, arsine, colophony, epoxy } \\
\text { resins, glues and resins research, heavy metals, metal working fluids, } \\
\text { mineral oils, vibration, cement research }\end{array}$ \\
\hline Display screen equipment & 39 & Includes work related upper limb disorder and repetitive strain injury \\
\hline Infection, pathogens & 29 & $\begin{array}{l}\text { Includes genetically modified organisms, laboratory and unspecified } \\
\text { bloodborne viruses, foreign travel, zoos, biological agents, } \\
\text { microorganisms }\end{array}$ \\
\hline Sickness absence & 16 & $\begin{array}{l}\text { Includes lack of an absence policy and non-specific poor management } \\
\text { of sickness absence }\end{array}$ \\
\hline Radiation & 15 & \\
\hline Poor management & 13 & $\begin{array}{l}\text { Includes ignorant management, management apathy, poor } \\
\text { management of health surveillance, lack of involvement of the OHS in } \\
\text { decision making, poor organisation of occupational health and safety } \\
\text { provision, lack of resource for the OHS, poor health promotion } \\
\text { opportunities }\end{array}$ \\
\hline Accidents & 10 & Includes machinery \\
\hline Clinical workers & 9 & Includes nurses and optometrists \\
\hline Noise & 8 & \\
\hline Lasers & 6 & \\
\hline Construction work & 5 & $\begin{array}{l}\text { Includes buildings and estates workers, and hand-arm vibration } \\
\text { syndrome in buildings and estates workers }\end{array}$ \\
\hline Alcohol and drugs & 3 & \\
\hline Other named hazards & 11 & $\begin{array}{l}\text { Includes farming and agriculture, asbestos, marine biology, scientific } \\
\text { diving, dust, detergents }\end{array}$ \\
\hline $\begin{array}{l}\text { Other named occupational } \\
\text { health concerns }\end{array}$ & 16 & $\begin{array}{l}\text { Student occupational health, management referrals, audiometry for } \\
\text { music teachers, university drivers, night workers, lone workers, food } \\
\text { handlers, cardiovascular disease, harassment and bullying, hoaxes } \\
\text { and threats, road traffic through campus, smoking }\end{array}$ \\
\hline Total & 389 & \\
\hline
\end{tabular}

Reports from 95 of 117 universities and constituent parts of federal universities. 
implications for the way the employee works, and the way employers manage them. There may be little incentive, for example, to make major changes to processes when a research project is short term. When the short term nature of students' courses is also considered, universities have a large number of workers with only a short term commitment to the organisation where they work. This may be unusual for employment sectors with the hazard profile of the university sector. Universities are also unusual workplaces in that they have a large number of visitors such as academic visitors, contractors, and members of the public visiting museums, libraries, sports centres, public spaces, and conference facilities.

The literature review identified many observations that the working culture in universities has changed in recent decades and that this has adversely affected the health of the staff. The working culture depends on background levels of funding and on government priorities in relation to higher education. In a study for the Association of University Teachers in the United Kingdom, Kinman and Jones (2004) commented that student numbers have increased dramatically in the UK, doubling the ratio of students to staff. ${ }^{63}$ This has occurred in parallel with the introduction of research assessment and teaching quality assessment procedures which are linked to funding and are perceived to have led to recent well publicised closures of entire academic departments. Tytherleigh et al (2005) commented that "universities no longer provide the low stress working environments they once did". ${ }^{64}$

Other factors relevant to occupational health needs include university funding, much of which comes from research grants and contracts, or from charitable donations. Such funding is usually targeted on specific projects and there may be little flexibility to cover infrastructure costs which may be relevant to occupational health, such as protective clothing, central occupational health and safety provision, or modifications to buildings.

Occupational mortality and morbidity statistics in the UK appear to group all education sectors together, despite their differences. This review has shown that university employees merit being considered as a group of interest in their own right and we recommend that the presentation of official statistics should reflect this. From 2003-04, the Higher Education Statistics Agency has started collecting routine data from all universities on all staff and this is welcome.

In summary, this review has demonstrated that the university sector in the UK and, we would predict, in other countries, is large and has a wide range of occupational health needs. We believe that this is the first time that information from several sources has been reviewed. Our findings suggest that this large and diverse employment sector may have been overlooked as a focus for national occupational health prevention policies and programmes. Currently available sector-wide guidance from 1991 for the $\mathrm{UK}^{1}$ and 1984 for the US ${ }^{2}$ requires updating. The review suggests that individual universities, and the sector as a whole, should review their occupational health needs to assess whether their occupational health provision is proportionate to those needs.

\section{ACKNOWLEDGEMENTS}

The Higher Education Funding Council for England funded this project (GMP 229) as part of its Good Management Practice programme; Pramod Philip and Alistair Townsend of the Funding Council provided invaluable advice and information. The Funding Council had no involvement in study design; in the collection, analysis, and interpretation of data; in the writing of the report; or in the decision to submit the paper for publication. Information in table 2 and appendix 2 is reproduced with the permission of Universities UK; we thank John Parrett. Information in tables 2 and 3, figure 1, and appendix 3 are reproduced with the permission of the Higher Education Statistics Agency; we thank Izzy Garnier. The Agency does not accept responsibility for any conclusions or inferences derived from the data by third parties. Information in table 4 is Crown copyright and is reproduced with the permission of the Controller of Her Majesty's Stationery Office; we thank Folkert van Galen for data from 1991 and 2001. Information in table 5 is from the Health and Occupation Reporting network; we thank John Osman of the Health and Safety Executive and Raymond Agius and the project team at the University of Manchester. We thank the membership of Higher Education Occupational Physicians for helpful discussion on many different aspects of the project. Adele Mayhew, Sageet Amlani, June Pedlar, Kate Stevens, Annelie Niklasson, and Eileen Kennedy provided administrative support.

\section{Authors' affiliations}

K M Venables, University Lecturer in Occupational Medicine, University of Oxford, Oxford, UK

S Allender, Research Fellow, University of Oxford, Oxford, UK

Competing interests: Dr Venables has been a member of the Health and Safety Executive working group on occupational health provision in higher and further education from 2002. This research has no connection with the Health and Safety Executive and does not reflect its views.

\section{REFERENCES}

1 Health and Safety Commission. Occupational health services in higher education. London: HMSO, 1991.

2 American College Health Association. Recommended standards and practices for a college health program. J Am Coll Health Assoc 1984;32:135-82

3 Department for Education and Employment. Obtaining occupational health advice on fitness to teach: a guide for teacher employers and managers and for college admissions and pastoral care tutors. London: HMSO, 2000.

4 Department for Education and Employment and the Faculty of Occupational Medicine. Fitness to teach: occupational health guidance for the training and employment of teachers. London: HMSO, 2000.

5 Venables KM, Allender S, Mayhew A. Occupational health services in higher education: first annual report of a project supported by the HEFCE Good Management Practice Programme (GMP 229), Internal report, Department of Public Health, University of Oxford, April 2003.

6 Graham G. Universities: The recovery of an idea. Thorverton: Imprint academic, 2002.

7 Committee on Higher Education. Higher Education: Report of the committee appointed by the Prime Minister under the chairmanship of Lord Robbins, 1961-63. London: HMSO, 1963.

8 DeRoos RL. Environmental health and safety in the academic setting Am J Public Health 1977;67:851-4.

9 Gunn ADG. Occupational health and safety a new 'imposition' for college staff. J Am Coll Health Assoc 1979;28:67-8.

10 Berger BA. Corporate responsibility for recombinant DNA activities. U Toledo Law Rev 1981;12:913-24.

11 Hurst R, Khalil TM. Universities need adequate employee safety, health programs. Occup Health Safety 1986;55:39-43.

12 Spickett JT. Occupational health and safety in tertiary educational institutions. J Occup Health Safety - Aust NZ 1988;4:417-21.

13 Shuttleworth P. A marriage of convenience or one made in heaven? Occup Health 1996:322-3.

14 Emery R, Delclos G, Cooper SP, et al. Evaluating the relative status of health and safety programs for minority academic and research institutions. Am Ind Hyg Assoc J 1998;59:882-8.

15 Efthymiou ML. La medicine du travail dans les universities. Arch Mal Prof Med 1984;45:485-9.

16 Tucker PJ, Caldwell SB, Spickard WA. A university medical center occupational health service: shoes for the cobbler's children. Arch Intern Med 1978;138:77-9.

17 Dordan A. Une infirmiere en milieu universitaire. Soins 1982;389:17-24.

18 Rojas-Martini M, Squillante G, Espinoza C. Condiciones de trabajo y salud de una universidad Venezolana. Salud Publica Mex 2002;44:413-21.

19 Sheps SB, Spengler RF, Pless IB. Utilization of the preemployment health examination in a university staff health service. $J$ Occup Med 1979;21:468-70

20 Pennington H. Smallpox Scares. London Review of Books. 5 September 2002; $24: 17$

21 Stark A. Policy and procedural guidelines for the health and safety of workers in virus laboratories. Am Ind Hyg Assoc J 1975;36:234-40.

22 Wennborg $\mathbf{H}$, Bonde JP, Stenbeck $M$, et al. Adverse reproduction outcomes among employees working in biomedical research laboratories. Scand J Work Environ Health 2002;28:5-11.

23 Klein RC, Party E, Gershey EL. Removable surface contamination at a biomedical research institution. Health Phys 1997:72:296-9. 
24 Edwards B, Barnes L, Gibbs B, et al. Development of a laser safety hazard evaluation procedure for the research university setting. Health Phys 2002;82(suppl 1):S37-S46.

25 Hallock MF, Martin KP, Mendes BA, et al. Development of a program for performance evaluation of university specialty local exhaust systems for compliance with the OSHA laboratory standard. Appl Occup Environ Hyg 1996;11:167-73.

26 Guarino J. Health and safety surveys at university chemistry laboratories. Appl Occup Environ Hyg 1990;5:289-92.

27 Mecklem RL, Neumann CM. Defining and managing biohazardous waste in U.S. research-oriented universities: a survey of environmental health and safety professionals. J Environ Health 2003;66:17-22.

28 Crawford A. Laboratory safety under the microscope. Health and Safety at Work 1987;9:22-24

29 Goodwin V, Cobbin D, Logan P. Examination of the occupational health and safety initiatives available within the chemistry departments of Australian universities. J Chem Educ 1999:76:1226-9.

30 Rombeck A, Schacke G. Umgang mit Gefahrstoffen und Umsetzung der Gefahrstoffverordnung an Hochschulinstituten aus arbeitsmedizinischer Sicht [Handling of hazardous substances and the implementation of the ordinance governing hazardous substances at university institutes seen in the light of occupational medicine]. Zbl Arbeitsmed 2000;50:114-27.

31 O'Neill TM, Abbott AV, Radecki SE. Risk of needlesticks and occupational exposures among residents and medical students. Arch Intern Med 1992;152:1451-6

32 Birenbaum D, Wohl A, Duda B, et al. Medical students' occupational exposures to potentially infectious agents. Acad Med 2002;77:185-9.

33 Turner HS, Hurley JL, Butler KM, et al. Accidental exposures to blood and other body fluids in a large academic medical center. J Am Coll Health 1999:47:199-206.

34 Shultz CM, Harris J, Shultz SL. Accidental needlestick injuries in the academic setting: a model follow-up program. Nurse Educator 1994;19:23-31.

35 Khurana V, Kar P, Mansharamani N, et al. Differences in hepatitis B markers between clinical and preclinical health care personnel. Trop Gastroenterol 1997; 18:69-71.

36 Diekema DJ, Ferguson KJ, Doebbeling BN. Motivation for hepatitis B vaccine acceptance among medical and physician assistant students. J Gen Intern Med 1995;10:1-6.

37 Savage NW, Walsh $\amalg$. Integrating infection control into the dental curriculum. Aust Dent J 1997;42:395-8.

38 Wilkins D, Woolcock AJ, Cossart YE. Tuberculosis: medical students at risk Med J Aust 1994;160:395-7.

39 Meade GM. The prevention of primary tuberculous infections in medical students: the autopsy as a source of primary infection. Am Rev Tuberc 1948;58:675-83

40 Murphy DC, Younai FS. Challenges associated with assessment of risk for tuberculosis in a dental school setting. Am J Infect Control 1996:24:254-61.

41 Arbelaez MP, Ocampo MC, Montoya J, et al. Evaluacion de la respuesta a la tuberculina en estudiantes del area de la salud [Evaluation of the response to tuberculin among university students in the health field]. Rev Panam Salud Publica 2000;8:272-9.

42 Russell LH, Goswick CB, Flowers Al. Accidental exposure of veterinary students to rabies. J Am Vet Med Assoc 1977;171:1184-6.

43 Duclos PJ, Bentejac M-C, Serre A, et al. Skin test reactions to a phenol-soluble antigen of Brucella abortus among veterinary students, Lyon, France, 1984 Int J Epidemiol 1989:2:446-50.

44 Hubbert WT. Occupational health and safety programs in schools of veterinary medicine. Health Lab Sci 1978;15:210-14.

45 McCann M. Health and safety programs for art and theater schools. Occup Med. State of the Art Reviews 2001;16:659-77.

46 Lucas AD, Salisbury SA. Industrial hygiene survey in a university art department. J Environ Pathol Toxicol Oncol 1992;11:21-7.

47 Lu PC. A health hazard assessment in school arts and crafts. J Environ Pathol Toxicol Oncol 1992;11:12-17.

48 Zaza C, Farewell VT. Musicians' playing-related musculoskeletal disorders: an examination of risk factors. Am J Ind Med 1997;32:292-300.

49 Guptill C, Zaza C, Paul S. An occupational study of physical playing-related injuries in college music students. Med Probl Perform Ar 2000;15:86-90.
50 Lundy DS, Casiano RR, Sullivan PA, et al. Incidence of abnormal laryngea findings in asymptomatic singing students. Otolaryng Head Neck 1999:121:69-77.

51 Henoch MA, Chesky K. Sound exposure levels experienced by a college jazz band ensemble: comparison with OSHA risk criteria. Med Probl Perform Ar 2000;15:17-22.

52 Barss $\mathbf{P}$, Hall TM. Injuries and illnesses aboard research vessels of the University National Oceanographic Laboratory System. J Occup Med 1990;32:116-23.

53 Burr GA. Lead exposure during custodial activities. Appl Occup Environ Hyg $1997 ; 12: 395-9$.

54 Rizzo TH. Office ergonomics education: a health promotion program at Stanford University. Am J Health Promot 1993:8:15-18.

55 Office of Population Censuses and Surveys. Occupational mortality: The Registrar General's Decennial Supplement for England and Wales, 1960-62. London: HMSO, 1971.

56 Office of Population Censuses and Surveys. Occupational mortality: The Registrar General's Decennial Supplement for England and Wales, 1970-72. London: HMSO, 1978.

57 Office of Population Censuses and Surveys. Occupational mortality: the Registrar General's decennial supplement for Great Britain 1979-80, 198283. Part 1: commentary. London: HMSO, 1986.

58 Craig AR, Bauman A, Cubbage $M$, et al. Health status inequity: occupation and prevalence of risk factors for heart disease in university staff. $J$ Occup Health Safety - Aust NZ 1990;6:119-25.

59 Buchankova J, Kruty F, Klimentova G, et al. Profesionalne choroby $v$ rezorte skolstva a vedy $v$ rokoch 1967-96 [Occupational diseases in the area of education and science in 1967-1996]. Pracov Lek 1997;49:165-71

60 Kohout J, Noskova J. Nemoci z povolani u pracovniku ve skolstvi v zapadoceskem regionu [Occupational diseases of workers in education in the west Bohemian region]. Prakt Lek 2000;80:496-7.

61 Stansfeld SA, Head J, Rasul F, et al. Occupation and mental health: secondary analyses of the ONS psychiatric morbidity survey of Great Britain. Norwich: HMSO, 2003.

62 Fisher S. Stress in academic life: the mental assembly line. Buckingham: The Society for Research into Higher Education and Open University Press, 1994.

63 Kinman G, Jones F. Working to the limit: stress and work-life balance in academic and academic-related employees in the UK. London: Association of University Teachers, 2004

64 Tytherleigh MY, Webb C, Cooper CL, et al. Occupational stress in UK higher education institutions: a comparative study of all categories. Higher Education Research and Development 2005;24:41-61.

65 Niven C, Cutler MG. The perception of occupational stress and its relation to research and teaching among academic staff. Work \& Stress 1995:9:540-3.

66 Michailidis M. Asimenos A. Occupational stress as it relates to higher education, individuals and organizations. Work 2002;19:137-47.

67 Gillespie NA, Walsh M, Winefield AH, et al. Occupational stress in universities: staff perceptions of the causes, consequences and moderators of stress. Work \& Stress 2001;15:53-72.

68 MacDonald NE, Davidson S. The wellness program for medical faculty at the University of Ottawa: a work in progress. CMAJ 2000;163:735-8.

69 Christophoro R, Pagliarini-Waidman MA. Estresse e condiceones de trabalho: um estudo com docents do curso de enfermagem da UEM, Estado do Parana [Stress and conditions of work: a study with nursing professors]. Acta Scient 2002;24:757-63.

70 Koumans AJ, Fleming RC. A personal assistance program for troubled employees at a large university: formation, implementation, and results. J Am Coll Health Assoc 1980;289:218-21.

71 Balgopal PR, Stollak MJ. The structure and functions of employee assistance programs in higher education. Employee Assistance Quarterly 1992;8:89-104.

72 Blaze-Temple D, Howat P, Barney J, et al. Legislative and humanitarian impetus for development of alcohol and other drug policy at an Australian university. Comm Health Stud 1989:13:463-70.

73 Barker JW, Glass JC. Perceived wellness needs of university employees. J Am Coll Health 1990;38:187-9

74 Black O, Richardson I, Herbert R. Jobs in the public sector mid-2003. Labour Market Trends 2004;112:271-81. 